\title{
POTENSI MODIFIKASI PATI DENGAN ESTERIFIKASI SEBAGAI PREBIOTIK
}

\section{Masrukan $^{11}$}

\begin{abstract}
Foodstuffs derived from starch are an important source of energy for society and in fact they also make a fairly specific contribution to health. Starch modification can result in resistant starch in the human digestive tract. Resistant starch from chemical modification by esterification has been known to improve its physical, chemical, and functional properties as well as to have health benefits. Resistant starch positively affects digestive tract function, microbes, glycemic index and helps in diabetes control. Apart from having health effects, resistant starch also has sensory properties that do not change much when compared to sources of starch fiber, such as whole grains, fruits or bran. Among the physicochemical properties of resistant starch are its swelling capacity, viscosity, gelling capacity and water-binding capacity, which makes it useful in a variety of foods.
\end{abstract}

\begin{abstract}
Abstrak
Bahan makanan yang bersumber dari pati adalah sumber energi penting bagi masyarakat dan secara nyata juga memberikan kontribusi yang cukup spesifik untuk kesehatan. Modifikasi pati dapat mengahasilkan pati yang tahan cerna di dalam saluran pencernaan manusia. Pati resisten dari modifikasi kimia secara esterifikasi telah diketahui meningkatkan sifat fisik, kimia, dan sifat fungsionalnya serta mempunyai manfaat kesehatan. Pati resisten secara positif mempengaruhi fungsi saluran pencernaan, mikroba, indeks glikemik dan membantu dalam pengendalian penyakit diabetes. Selain mempunyai efek kesehatan, pati resisten juga mempunyai sifat sensoris yang tidak banyak mengalami perubahan apabila dibandingkan dengan sumber serat pati, seperti biji-bijian utuh, buah-buahan atau dedak. Di antara sifat fisikokimia dari pati resisten adalah kapasitas pembengkakan, viskositas, pembentukan gel dan kapasitas pengikat airnya, yang membuatnya berguna dalam berbagai makanan.
\end{abstract}

\footnotetext{
${ }^{1}$ Program Studi Teknologi Pangan Fakultas Teknologi Pertanian Universitas Widya Mataram Yogyakarta Email: mrukan@gmail.com
} 


\section{Pendahuluan}

Pati merupakan salah satu jenis polisakarida yang banyak dijumpai pada tanaman. Secara histologi pati terdapat dalam sel, berbentuk butiran-butiran kecil (granula) yang dinamakan amiloplas atau kloroplas, berikatan dengan air, lemak, dan senyawasenyawa lainnya. Pati merupakan polimer dari satuan $\alpha$-D-glukosa (anhidroglukosa) dengan rumus empiris $\left(\mathrm{C}_{6} \mathrm{H}_{10} \mathrm{O}_{5}\right)_{\mathrm{n}}$. Pati disusun oleh dua satuan polimer utama yaitu amilosa dan amilopektin. Molekul amilosa merupakan polimer dari unit-unit glukosa dengan bentuk ikatan $\alpha-(1,4)-D-g l i k o s i d i k$, berbentuk rantai lurus, tidak bercabang atau mempunyai struktur heliks yang terdiri dari 200 - 2000 satuan anhidroglukosa. Sedangkan amilopektin merupakan polimer unit-unit glukosa dengan ikatan $\alpha-(1,4)-D$-glikosidik pada rantai lurusnya dan ikatan $\alpha-(1,6)$-D-glikosidik pada percabangannya yang terdiri dari 10.000 100.000 satuan anhidroglukosa (Itthisoponkul et al., 2007). Struktu molekul amilosa dan amilopektin dapat dilihat pada Gambar 1.
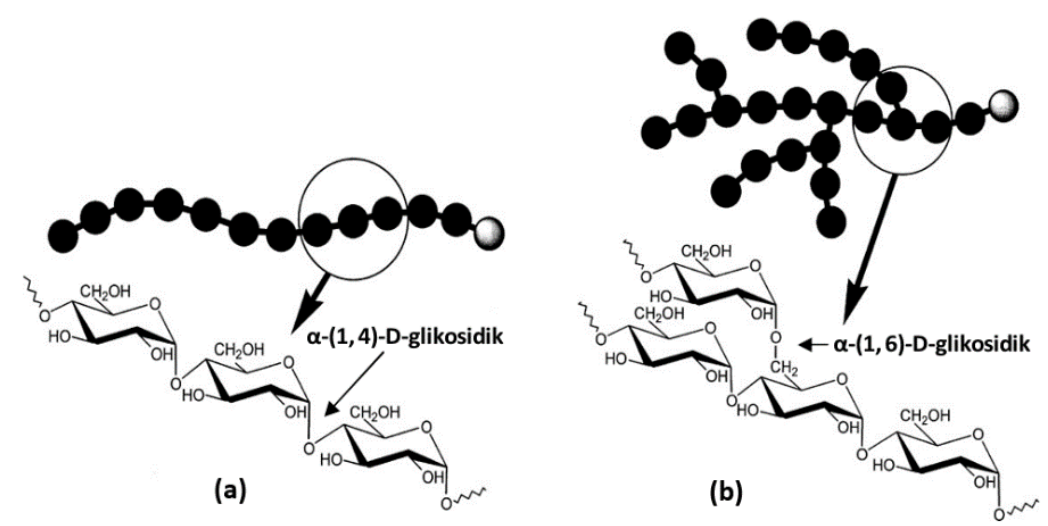

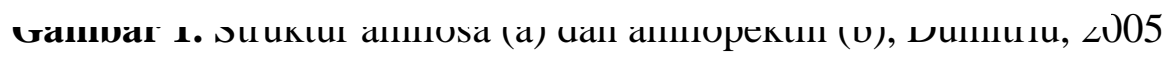

Pati alami dari berbagai sumber tanaman pada umumnya memiliki sifat-sifat yang membatasi penggunaannya dalam aplikasinya dalam berbagai produk pangan. Perbaikan sifat fisik dan kimia pati alami bisa dilakukan, antara lain dengan cara modifikasi pati. Penelitian tentang modifikasi pati telah banyak dilakukan hingga saat ini, akan tetapi pada umumnya penelitian tersebut hanya difokuskan pada upaya untuk memperbaiki sifat fisik dan kimia pati saja. Di sisi lain modifikasi pati memiliki potensi yang besar untuk memberikan efek 
fungsional terhadap kesehatan orang yang mengkonsumsinya. Pati termodifikasi, terutama hasil modifikasi dengan cara esterifikasi, lebih tahan cerna dibandingkan pati alami karena menyisakan bagian pati tahan cerna (resistant starch, RS) yang kemudian memberikan efek yang menyehatkan terhadap kolon dalam sistem pencernaan makanan.

\section{Modifikasi pati secara kimia}

Modifikasi merupakan perubahan struktur molekul pati yang dapat dilakukan dengan cara fisik, kimia (eterifikasi, esterifikasi, oksidasi dan ikatan silang) dan enzimatik. Setiap perlakuan modifikasi pada jenis pati yang bermacam-macam menghasilkan karakteristik pati modifikasi yang berbeda-beda (Volkert et al., 2010).

Esterifikasi merupakan salah satu metode modifikasi pati secara kimia yang menghasilkan pati termodifikasi yang lebih sulit dicerna oleh enzim amilolitik yang ada dalam sistem pencernaan, sehingga menyisakan sejumlah pati tahan cerna (resistant starch, RS) karena perubahan struktur beberapa satuan glukosa pada molekul pati (Perera et al., 2010). Perubahan struktur pada pati dapat meningkatkan kadar pati resisten. Selanjutnya RS masuk ke dalam kolon dan digunakan sebagai substrat bagi mikroflora kolon menghasilkan short chain fatty acid (SCFA) yang bermanfaat bagi kesehatan kolon.
Modifikasi secara kimia tergantung pada reaktivitas dari gugus hidroksi $(\mathrm{OH})$ yang terdapat di dalam molekul gula. Pati yang termodifikasi secara kimiawi disebut juga derivat pati atau turunan pati. Modifikasi secara kimiawi dapat dilakukan dengan cara oksidasi, eterifikasi dan esterifikasi, tergantung dari karakteristik pati termodifikasi yang dikehendaki. Modifikasi pati secara oksidasi biasanya dilakukan dengan tujuan untuk mendapatkan pati termodifikasi dengan karakteristik: (1) memiliki viskositas rendah, (ii) memiliki kecepatan retrogradasi rendah, (iii) lebih cepat tergelatinisasi, (v) memiliki kejernihan lebih baik, dan (vi) pada suhu dingin tidak membentuk gel yang rigid. Modifikasi secara eterifikasi biasanya dilakukan untuk mendapatkan pati termodifikasi dengan karakteristik: (i) memiliki kecepatan retrogradasi dan suhu gelatiniasasi yang rendah, (ii) stabil pada suhu beku, dan (iii) mudah dimasak. Modifikasi secara esterifikasi dilakukan dengan tujuan untuk mendapatkan pati termodifikasi dengan karakteristik: (i) memiliki kecepatan retrogradasi lebih lambat, stabil pada suhu rendah, panas dan kondisi asam, (ii) serta memiliki kejernihan pasta lebih baik dan mudah dimasak (Cereda et al.,2003).

Pada modifikasi kimia pati secara esterifikasi, terdapat tiga gugus $\mathrm{OH}$ pada atom C2, C3 dan C6 pada satuan glukosa yang dapat 
disubstitusi oleh gugus asil melalui reaksi adisieliminasi dengan keberadaan senyawa intermediet yang terbentuk (Muljana et al., 2010). Reaktivitas gugus $\mathrm{OH}$ berbeda pada atom $\mathrm{C} 2$, $\mathrm{C} 3$ dan $\mathrm{C} 6$, gugus $\mathrm{OH}$ pada atom $\mathrm{C}$ primer (C6) lebih reaktif daripada gugus $\mathrm{OH}$ pada atom
$\mathrm{C}$ sekunder (C2 dan $\mathrm{C} 3)$ dan gugus $\mathrm{OH}$ pada atom C2 lebih reaktif daripada C3 karena sifat sterik atom C3 (Diop et al., 2011). Pada Gambar 2, dapat dilihat mekanisme reaksi esterifikasi.

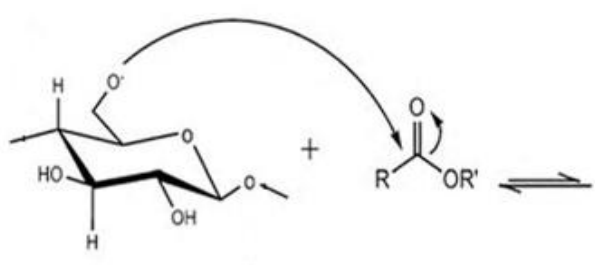

(1)
(2)

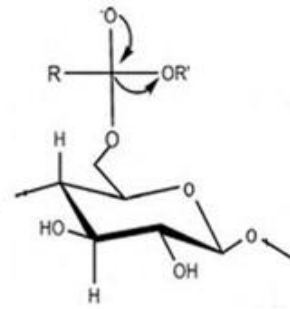

(3)

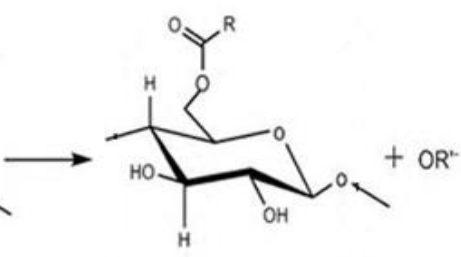

(4)

Gambar 2. Mekanisme reaksi esterifikasi, Muljana et al., 2010

Berbagai cara modifikasi kimia pada pembuatan pati secara esterifikasi. Diantaranya adalah pati asetat, pati oktenil suksinat, dan pati butirat. Asetilasi maltodekstrin dengan vinil asetat menghasilkan maltodekstrin asetat yang mengalami substitusi pada atom C2, C3 dan C6 (Shogren dan Biswas, 2010). Modifikasi pati jagung ketan (waxy maize) dengan oktenil suksinat anhidrida menghasilkan pati oktenil suksinat yang mengalami substitusi pada atom C2 dan C3 (sedangkan modifikasi maltodekstrin dengan oktenil suksinat anhidrida menghasilkan maltodekstrin oktenil suksinat yang mengalami substitusi pada atom C2, C3 dan C6 (Bai et al., 2011).

\section{Faktor-faktor yang berpengaruh dalam proses modifikasi pati \\ pH}

Pada proses modifikasi pati, terutama proses modifikasi dengan cara esterifikasi, $\mathrm{pH}$ suspensi berperanan dalam proses keberhasilan reaksi. Hasil penelitian sebelumnya bahwa $\mathrm{pH}$ berpengaruh terhadap gugus asetil yang terikat pada molekul glukosa dan efisiensi reaksi. 
Proses modifikasi pati jagung dan pati amaranth pada umumnya dilakukan pada $\mathrm{pH}$ antara 7,0 - 11,0. Untuk mendapatkan hasil yang optimum, proses modifikasi pati jagung dan pati amaranth dilakukan pada $\mathrm{pH}$ 8,0. Contoh lain adalah modifikasi pati jagung dengan phosporilasi diperoleh kondisi optimum pada pH 12 (Kahraman et al., 2015). Apabila reaksi esterifikasi dilakukan pada $\mathrm{pH}$ lebih dari 8,0, maka pati mudah mengalami hidrolisis, sedangkan apabila proses esterifkasi dilakukan pada $\mathrm{pH}$ kurang dari 8,0, maka tidak cukup efektif bagi gugus hidroksil sebagai nukleofil dari pati untuk menyerang butirat anhidrida, sehingga proses esterifikasi tidak dapat terjadi secara efektif (Bhosale dan Singhal, 2006). Pada pembuatan pati termodifikasi secara kimiawi, khususnya dengan esterifikasi akan sangat dipengaruhi karakteristik granula bahan baku pati, serta komposisi rasio amilosa dan amilopektinya.

\section{Konsentrasi reaktan}

Konsentrasi reaktan juga berpengaruh terhadap modifikasi pati. Kecepatan reaksi akan meningkat dengan meningkatnya konsentrasi reaktan yang dapat dijelaskan dengan teori tumbukan. Bila konsentrasi reaktan meningkat, maka frekuensi tumbukan antara partikel akan meningkat. Berdasarkan teori tumbukan, konsentrasi reaktan memegang peranan penting dalam tumbukan antar partikel akan menghasilkan reaksi dan akan menghasilkan energi tumbukan sehingga akan memungkinkan terjadinya benturan antar partikel. Dua reaktan dapat bereaksi bersama bila antara satu reaktan dengan reaktan lainnya saling kontak. Pertama yang terjadi adalah benturan antara satu reaktan dengan reaktan lainnya, dan kedua adalah terjadinya reaksi. Namun demikian tidak semua benturan antar molekul dapat menyebabkan terjadinya reaksi. Benturan antar molekul dapat menyebabkan terjadinya reaksi bila memiliki energi aktivasi minimum. Energi aktivasi adalah energi minimum yang diperlukan sehingga memungkinkan terjadinya tumbukan antar molekul sehingga memungkinkan terjadinya reaksi (Solomons, 1990). Bila energi yang dihasilkan karena terjadinya benturan antar partikel lebih kecil bila dibandingkan dengan energi aktivasi, maka tidak akan terjadi reaksi.

Pada modifikasi pati dengan menggunakan oktenil suksinat anhidrida (OSA), peningkatan derajat subsitusi (DS) dapat terjadi seiring dengan peningkatan konsentrasi OSA. Menurut Bhosale dan Singhal (2006), bahwa makin meningkat konsentrasi OSA makin besar ketersediaan molekul OSA untuk bereaksi dengan molekul pati. Hal ini dikarenakan bahwa gugus hidroksil pati bersifat immobile sehingga reaksinya dengan molekul OSA sangat 
tergantung pada ketersediaan molekul OSA yang terdapat disekitar gugus $\mathrm{OH}$.

Konsentrasi reagent berbeda untuk mendapatkan pati ester yang berbeda, walaupun derajat subsitusi (DS) yang dikehendaki adalah sama. Sebagaimana yang dilaporkan oleh Annison et al. (2003) bahwa untuk mendapatkan pati jagung asetat, propionat dan butirat dengan DS 0,2 diperlukan asetat anhidrida, propionat anhidrida dan butirat anhidrida, berturut-turut sebanyak 19,17; 30,00 dan 38,33\% (v/w).

\section{Suhu}

Suhu merupakan salah satu faktor yang berpengaruh terhadap proses modifikasi pati. Bila suhu meningkat, maka kecepatan reaksi akan meningkat karena makin banyak energi yang masuk ke dalam sistem. Di samping itu dengan meningkatnya suhu, maka dapat menyebabkan meningkatnya benturan antar partikel. Namun demikian untuk meningkatkan kecepatan reaksi tetap membutuhkan energi aktivasi, sehingga tumbukan antara partikel akan meningkat. Suhu dalam proses esterifikasi sangat berpengaruh terhadap besar kecilnya DS pati ester. Berdasarkan hasil penelitian sebelumnya diketahui bahwa proses esterifikasi pada suhu tinggi dapat menghasilkan pati asetat dengan DS yang tinggi.

Esterifikasi pati jagung kaya amilosa dengan asetat anhidrida yang dilakukan pada suhu $123{ }^{\circ} \mathrm{C}$ dapat diperoleh pati asetat dengan DS 2,23. Hasil penelitian lain menunjukkan bahwa proses esterifikasi pati jagung kaya amilosa dengan asetat anhidrida yang dilakukan pada suhu 50, 65 dan $75^{\circ} \mathrm{C}$ dapat diperoleh pati asetat dengan DS masing-masing sebesar 0,85; 1,78 dan 2,89 (Chi et al., 2008).

\section{Lama waktu reaksi}

Lama waktu reaksi sintesis berpengaruh terhadap nilai DS pati modifikasi. Waktu reaksi yang lebih lama diketahui akan menurunkan efisiensi reaksi, karena terjadi reaksi hidrolisis. Pada proses asetilasi pati Xanthosoma violaceum diketahui bahwa efisiensi reaksi tertinggi diperoleh dengan lama waktu reaksi 30 menit. Pengaruh lama waktu reaksi terhadap DS pada berbagai jenis pati adalah berbeda, tergantung pada jenis reagen, morfologi dan bentuk granula pati. Pada sintesis pati oktenil suksinat dari pati jagung diketahui bahwa DS menurun dari 0,018 menjadi 0,013 seiring dengan makin meningkatnya lama waktu reaksi dari 6 jam menjadi 48 jam, sedangkan pada waxy corn starch DS maksimum diperoleh pada lama waktu reaksi 24 jam (Bhosale dan Singhal, 2006). Peningkatan suksinilasi oktenil dengan memperpanjang lama waktu reaksi berdampak langsung pada proses difusi dan adsorpsi antara oktenil dengan molekul pati. Hasil ini 
menunjukkan bahwa setiap jenis pati memiliki karakteristik spesifik.

\section{Potensi pati resisten dari modifikasi pati secara kimia}

RS didefinisikan sebagai jumlah dari pati dan hasil pencernaan pati yang tidak diserap di dalam usus halus individu sehat. Secara analitis, RS didefinisikan sebagai pati yang tahan terhadap dispersi di dalam air mendidih dan hidrolisis amilase pankreas dan pullulanase, tetapi dapat didispersi oleh $\mathrm{KOH}$ dan dilanjutkan dihidrolisis oleh enzim $\alpha$ amilase, amiloglukosidase dan pullulanase (Englyst dan Cummings, 1987; dalam Marsono, 2004), artinya bahwa proses hidrolisis RS oleh enzim $\alpha$-amilase, amiloglukosidase dan pullulanase baru dapat terjadi apabila RS tersebut didispersikan terlebih dulu di dalam larutan $\mathrm{KOH}$. RS yang tidak didispersikan ke dalam larutan $\mathrm{KOH}$ tidak dapat dihidrolisis oleh ketiga jenis enzim tersebut.

RS diklasifikasikan menjadi lima tipe yang disebut RS1, RS2, RS3, RS4 dan RS5 (Fuentes-Zaragoza et al., 2010). RS1 adalah pati yang secara fisik terperangkap diantara dinding sel bahan pangan dan ditemukan pada serealia dan biji- bijian. RS 2 adalah granula pati yang tahan terhadap enzim pencernaan dan ditemukan pada pati kentang, pisang mentah dan pati amilosa tinggi. RS 3 adalah pati retrogradasi, yaitu pati yang dirubah konformasinya melalui pengolahan pangan (proses panas dan dingin). RS 4 adalah pati yang dimodifikasi secara kimia yang tahan terhadap hidrolisis enzim diantaranya pati eter, pati ester dan pati ikat silang (Sanz et al., 2009). RS 5 adalah pati yang membentuk komplek dengan minyak/lipid. Diskripsi dari masing-masing tipe RS disajikan pada Tabel 1.

Tabel 1. Klasifikasi dan diskripsi tipe pati resisten

\begin{tabular}{|l|l|l|l|}
\hline Tipe RS & Diskripsi & $\begin{array}{l}\text { Pencernaan dalam } \\
\text { usus halus }\end{array}$ & Sumber \\
\hline RS-1 & $\begin{array}{l}\text { Pati yang secara fisik } \\
\text { sulit dicerna }\end{array}$ & lambat & $\begin{array}{l}\text { serealia utuh/digiling } \\
\text { tidak halus }\end{array}$ \\
\hline
\end{tabular}




\begin{tabular}{|c|c|c|c|}
\hline RS-2 & Granula pati resisiten & Sangat lambat & $\begin{array}{l}\text { kentang dan pisang } \\
\text { mentah }\end{array}$ \\
\hline RS-3 & $\begin{array}{l}\text { Pati teretrogradasi } \\
\text { (resisten krn proses } \\
\text { pengolahan) }\end{array}$ & Lambat & $\begin{array}{l}\text { Pati resisten dalam } \\
\text { corn flakes, } \\
\text { rotitawar, lempeng }\end{array}$ \\
\hline RS-4 & $\begin{array}{lr}\text { pati yang } \\
\text { dimodifikasi fisik, } \\
\text { kimia atau ensimatik }\end{array}$ & $\begin{array}{ll}\text { Tahan terhadap } \\
\text { hidrolisis }\end{array}$ & pati-butyrat \\
\hline RS-5 & $\begin{array}{l}\text { komplek amilosa dan } \\
\text { lipid yang terjadi } \\
\text { secara alami maupun } \\
\text { karen aproses } \\
\text { pengolahan }\end{array}$ & Lambat & $\begin{array}{l}\text { amilo-lipid complex } \\
\text { ): contoh amilo-lipid } \\
\text { pada makanan } \\
\text { berlemak }\end{array}$ \\
\hline
\end{tabular}

Sumber : (Fuentes-Zaragoza et al., 2010)

\section{Sifat fungsional pati resisten sebagai prebiotik}

RS diketahui memiliki sifat fungsional yang menguntungkan bagi kesehatan yang mengkonsumsinya. Efek keshatan tersebut antara lain adalah RS dapat mencegah terjadinya kanker kolon, memiliki efek hipolipidemik dan meningkatkan absorpsi kolesterol, asam empedu, dan mineral (Ashwar et al., 2016). Salah satu contoh penerapan penggunaan RS dari pati jagung yang dimodifikasi secara phosporilasi adalah pada pembuatan cookies. Cookies yang dibuat dari RS tersebut terbukti menurunkan nilai indeks glikemik postprandial (Kahraman et al., 2019).

Prebiotik adalah ingredien pangan yang tidak dapat dicerna yang akan menstimulasi pertumbuhan dan atau aktivitas bakteri di dalam kolon, terutama yang dapat meningkatkan kesehatan Ingredien pangan 
yang memiliki sifat prebiotik adalah rafinosa, inulin, frukto oligosakarida (FOS), galaktosilaktosa, laktolusa dan RS. Menurut Brouns et al. (2002), RS memiliki sifat fungsional sebagai berikut: (i) dapat difermentasi oleh mikroflora usus, (ii) pada saat difermentasi gas yang terbentuk relatif sedikit, (iii) jumlah asam butirat lebih banyak dibandingkan dengan hasil fermentasi polisakarida bukan pati, (iv) bersifat selektif untuk pertumbuhan Bifidobacteria dan Lactobacilli, (v) menghambat pertumbuhan mikroba patogen yang terdapat di dalam usus, dan (vi) mengabsorpsi asam empedu, dan (vii) mengurangi toksisitas feses.

Komponen makanan dikatakan sebagai prebiotik apabila tidak dihidrolisis atau diserap dibagian atas saluran pencernaan, menjadi substrat selektif untuk satu atau sejumlah kecil bakteri yang menguntungkan di dalam kolon yang menstimulasi pertumbuhan dan aktivitas metabolisme bakteri tersebut, mengakibatkan perubahan koloni flora menjadi komposisi yang lebih sehat dan mendorong efek sistematis yang menguntungkan bagi kesehatan manusia (Wang, 2009). Beberapa syarat suatu komponen makanan dikategorikan sebagai prebiotik yaitu (i) resisten terhadap keasaman lambung, hidrolisis oleh enzim pencernaan mamalia dan penyerapan pada usus kecil, (ii) difermentasi oleh mikroflora usus besar, (iii) menstimulasi pertumbuhan dan atau aktivitas bakteri dalam usus besar yang memberikan kontribusi terhadap kesehatan (Roberfroid, 2007).

Prebiotik secara selektif digunakan oleh komponen yang menguntungkan flora usus dan tidak mendukung potensi patogen seperti racun yang dihasilkan oleh Clostridia, bakteri proteolitik dan toksigenik E. Coli. Bakteri dalam usus besar menghasilkan enzim untuk mencerna substrat yang mampu difermentasi yang masuk di dalam usus besar. Fermentasi secara anaerob memungkinkan bakteri untuk menggunakan hasil dari proses ini untuk mencukupi energi yang dibutuhkan untuk pemeliharaan dan pertumbuhan, sehingga meningkatkan biomassanya (Coles et al., 2005). RS selain dapat dimanfaatkan sebagai sumber karbon bagi bakteri probiotik, akan tetapi juga dapat dimanfaatkan sebagai sumber karbon bagi mikroba patogen di dalam kolon.

\section{Fermentasi RS di dalam kolon.}

Substrat utama bagi fermentasi oleh bakteri dalam kolon adalah karbohidrat yang lolos melewati saluran cerna bagian proksimal, yang terutama terdiri atas RS, disusul nonstarch polysaccharide, dan nondigestible oligosaccharide. Selain daripada itu juga 
protein yang lolos baik eksogen maupun endogen. Sehubungan dengan banyaknya jenis spesies yang hidup bersama dalam kolon, dengan kemampuan metabolisme yang sangat bervariasi, maka proses fermentasi dalam kolon sangat rumit. Produk akhir metabolisme satu spesies dapat menjadi substrat bagi spesies lainnya. Bacteroides, genus terbanyak, adalah pengguna polisakarida, di samping bakteri sakarolitik lainnya seperti Bifidobacteria, Ruminococcus, Eubacteria, Lactobacilli dan Clostridia. Proses metabolisme dalam kolon bergantung pada kerjasama berbagai enzim dari bermacam-macam spesies bakteri yang saling bergantung satu sama lain dalam rantai proses fermentasi.

Modifikasi dengan cara esterifikasi dapat menghasilkan pati termodifikasi dengan kandungan RS yang tinggi. RS tidak tercerna di dalam usus halus dan masuk ke dalam kolon. Di dalam kolon, RS dapat dimanfaatkan sebagai sumber karbon dalam proses fermentasi oleh mikroba kolon dan meningkatkan konsentrasi SCFA, khususnya asam asetat, asam propionat dan asam butirat, yang berpotensi fungsional pada kesehatan kolon karena dapat menurunkan $\mathrm{pH}$, mencegah kanker dan peradangan kolon (Beards et al., 2010). Peningkatan SCFA di dalam kolon sangat mungkin disebabkan karena hasil deesterifikasi substituen yang teresterifikasi pada molekul pati dan produk fermentasi mikrobia kolon.

Strategi meningkatkan SCFA akan memberikan keuntungan pada manusia. Salah satu strategi yang dapat dilakukan adalah meningkatkan konsumsi makanan yang banyak mengandung RS, sebab bila difermentasi akan menghasilkan asam butirat. Asam butirat merupakan penghasil energi utama bagi colonocyte karena oksidasi butirat mampu menyediakan lebih dari $70 \%$ oksigen untuk dikonsumsi jaringan kolon manusia (Brouns et al., 2002; Annison et al., 2003). Selain dapat mencegah terjadinya sel kanker pada kolon, asam butirat juga mampu menstimulasi sistem kekebalan tubuh melawan sel kanker (Brouns et al., 2002). Beberapa pengaruh SCFA terhadap kesehatan adalah sebagai berikut (Hijova dan Chmelarova, 2007):

1. Absorpsi SCFA di dalam kolon akan meningkatkan absorpsi air dan sodium serta meningkatkan sekresi bikarbonat

2. SCFA yang diabsorbsi oleh kolonisitas digunakan sebagai sumber energi dari sel-sel epitel mukosa kolonisitas. Peningkatan jumlah SCFA di dalam kolon akan menurunkan $\mathrm{pH}$ kolon yang secara tidak langsung akan mempengaruhi komposisi mikroflora kolon (meningkatkan mikroflora menguntungkan dan menurunkan 
jumlah mikroba patogen), menurunkan kelarutan asam empedu, jumlah amonia dan amina dan meningkatkan absorpsi mineral.

3. Asam propionat digunakan sebagai substrat untuk glukoneogenesis hepatik dan menghambat sintesis kolesterol dalam jaringan hepatik sehingga dapat menurunkan kolesterol plasma.
4. Butirat merupakan SCFA yang paling banyak digunakan sebagai sumber energi kolonisitas dan mempunyai sifat anti-inflamasi yang penting untuk menjaga kesehatan dan penyembuhan sel-sel kolon. Kondisi ini berimplikasi pada peranan butirat sebagai pengontrol diferensiasi, proliferasi dan apoptosis sel.

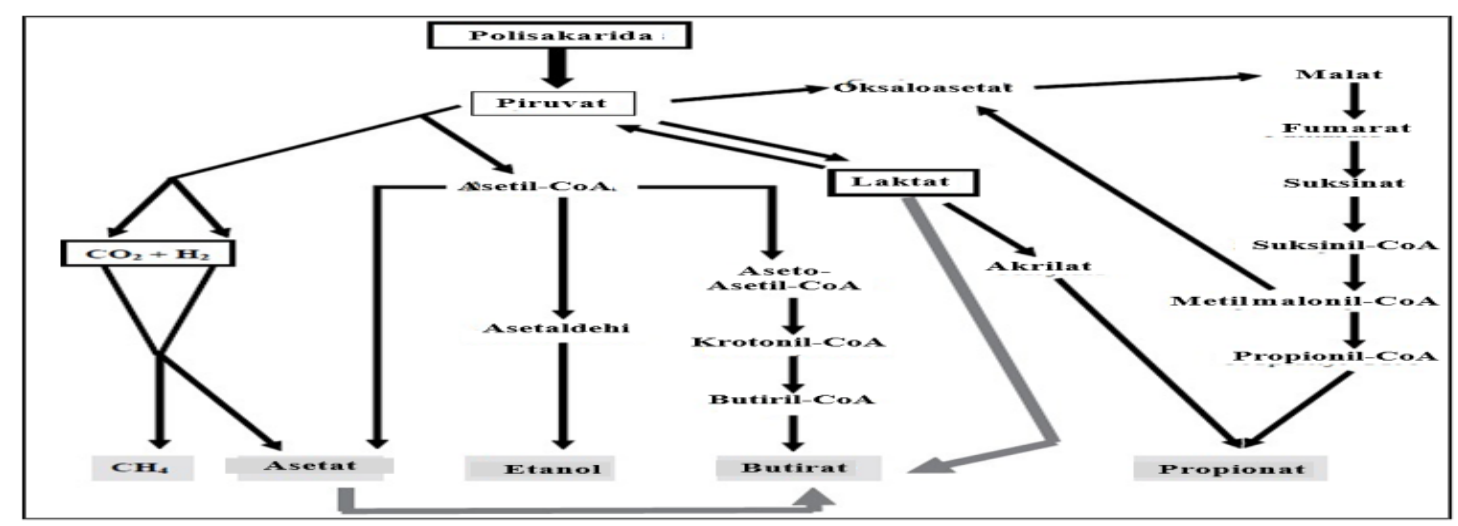

Gambar 3. Jalur metabolisme karbohidrat oleh bakteri didalam kolom (Donadille, 2010)

SCFA merupakan produk metabolit dari fermentasi polisakarida, oligosakarida, protein, dan peptide oleh bakteri anaerob di dalam kolon. Pada prinsipnya SCFA adalah asetat, propionat dan butirat, walaupun SCFA yang lainnya juga diproduksi akan tetapi dalam jumlah yang lebih sedikit. Pathway produksi SCFA di dalam kolon disajikan dalam Gambar 3.

\section{Kesimpulan}

Modifikasi secara kimiawi merupakan metode modifikasi pati yang paling banyak digunakan untuk menghasilkan pati termodifikasi. Modifikasi secara kimia tergantung pada reaktivitas gugus hidroksi yang terdapat di dalam molekul gula. 
Modifikasi dengan cara esterifikasi menghasilkan pati yang retrogradasinya lambat, stabil dalam pencernaan, dan komponen fungsionalnya meningkat. Pati termodifikasi lebih sulit dicerna oleh enzim karena perubahan struktur beberapa satuan glukosa pada molekul pati, sehingga menyebabkan kandungan RS meningkat. RS dari modifikasi kimia diduga memiliki kemampuan pengikatan air yang cukup besar sehingga mampu meningkatkan kadar air feses dan mengencerkan senyawa karsinogen dalam kolon. Peningkatan kadar air feses menyebabkan pertambahan berat dan volume feses sehingga isi lumen menjadi lebih bulky dan memberi efek mempercepat waktu transit feses di dalam kolon.

RS termasuk salah satu prebiotik untuk memacu pertumbuhan bakteri yang menguntungkan seperti Bifidobacteria dan Lactobacilli, serta dapat menghambat pertumbuhan bakteri yang merugikan seperti Bacteroides dan Clostridia. Oleh karena itu pati termodifikasi dapat dimanfaatkan sebagai makanan prebiotik untuk menjaga kesehatan usus. Produk fermentasi karbohidrat tak tercerna termasuk RS adalah asam lemak rantai pendek, terutama asam asetat, asam propionat dan asam butirat.

\section{Daftar pustaka}

Annison, G., Illman, R.J. and Topping, D.L. 2003. Acetylated, propionylated or butyrylated starches raise large bowel short chain fatty acids preferentially when fed to rats. J. Nutr. 133: 3523-3528.

Ashwar, B.A., Gani, A., Shah, A., Wani, I.A., Masoodi, F.A., 2016. Preparation, health benefits and applications of resistant starch - A review. Starch/Staerke 68, 287-301. https://doi.org/10.1002/star.201500064

Bai, Y. and Shi, Y.C. 2011. Structure and preparation of octenyl succinic esters of granular starch, microporous starch and soluble maltodextrin. Carbohydr. Polym. 83: $520-527$.

Beards, E., Tuohy, K. and Gibson, G. 2010. Bacterial, SCFA and gas profiles of a range of food ingredients following in vitro fermentation by human colonic microbiota. Anaerobe 16: 420 - 425.

Bhosale, R. and Singhal, R. 2006. Process optimization for the synthesis of octenyl succinyl derivative of waxy corn and amaranth starches. Carbohydr. Polym. 66: $521-527$.

Brouns, F., Kettlitz, B. and Arrigoni, E. 2002. Resistant starch and the butyrate revolution. Trends Food Sci. Technol. 13: 251-261.

Cereda, M.P., Vilpoux, O. and Demiate, I.M. 2003. Modified starch. Book technology, 
use and potentialities of latin american starchy tubers. CPC International, Milho, Brazil.

Chi, H., Xu, K., Wu, X., Chen, Q., Xue, D. and Song, C., Zhang, W. dan Wang, P. 2008. Effect of acetylation on the properties of corn starch. Food Chem. 106: 923-928.

Coles, L.T., Moughan, P.J. and Darragh, A.J. 2005. In vitro digestion and fermentation methods, including gas production techniques, as applied to nutritive evaluation of foods in the hindgut of humans and other simple-stomached animals. Anim. Feed Sci. Technol. 123-124: 421-444.

Diop, C.I.K., Li, H.L., Xie, B.J. and Shi, J. 2011a. Effect of acetic acid / acetic anhydride ratios on the properties of corn starch acetates. Food Chem. 126: 16621669

Donadille, A.B. 2010. Fermentative metabolism by the human gut microbiota. Gastroen. Clin. Biol. 34, Suppl. 1: S16-S22.

Dumitriu, S., Knil, C.J. and Kennedy, J.F. 2005. Polysaccharides: Structural Diversity and Functional Versatility. Marcel Dekker, Inc., New York.

Hijova, E. and Chmelarova, A., 2007. Short chain fatty acids and colonic health. Bratisl. Lek. Listy 108(8): 354-358.

Itthisoponkul, T., Mitchell, J.R., Taylor, A.J. and Farhat, I.A. 2007. Inclusion complexes of tapioca starch with flavour compounds. Carbohydr. Polym. 69: 106115.

Kahraman, K., Koksel, H., Ng, P.K.W., 2015. Optimisation of the reaction conditions for the production of cross-linked starch with high resistant starch content. Food Chem. 174 ,

173-179.

https://doi.org/10.1016/j.foodchem.2014.11 .032

Marsono, Y. 2004. Serat Pangan dalam Perspektif Ilmu Gizi. Pidato Pengukuhan Jabatan Guru Besar pada Fakultas Teknologi Pertanian, Universitas Gadjah Mada, Yogyakarta.

Muljana, H., Van Der Knoop, S., Keijzer, D., Picchioni, F., Jansen, L.P.B.M. and Heeres, H.J. 2010. Synthesis of fatty acid starch esters in supercritical carbon dioxide. Carbohydr. Polym. 82: 346 - 354.

Perera, A., Meda, V. and Tyler, R.T. 2010. Resistant Starch : A Review of Analytical protocol for determining resistant starch and of factors affecting the resistant starch content of food. Food Res. Int. 43: 1959 1974.

Roberfroid, M. 2007. Prebiotic: The Concept Revisited. J. Nutr. 137: 880s - 887s.

Sanz, T., Salvador, A., Baixauli, R. and Fiszman, S.M. 2009. Evaluation of four 
types of resistant starch in muffins. II. Effectin texture, colour and consumer response. Eur. Food Res. Technol. 229 (2): $197-204$.

Shogren, R.L. and Biswas, A. 2010. Acetylation of starch with vinyl acetate in imidazolium ionic liquids and characterization of acetate distribution. Carbohydr. Polym. 81: 149 - 151.

Topping, D. L., Fukushima, M. and Bird, A. R. 2003. Resistant starch as a prebiotic and synbiotic: State of the Art. Proc. Nutr. Soc. 62: 171-176.

Volkert, B., Lehmann, A., Greco, T. and Nejad, M.H. 2010. A comparison of different synthesis routes for starch acetate and the resulting mechanical properties. Carbohydr. Polym. 79: 571-577.

Wang, Y. 2009. Prebiotic: Present and future in food science and technology. Food Res. Int. 42: 8-12. 